STUDIA I PRACE WYDZIAKU NAUK EKONOMICZNYCH I ZARZĄDZANIA NR 39, t. 1

DOI:10.18276/sip.2015.39/1-07

Katarzyna Szopik-Depczyńska*

Uniwersytet Szczeciński

\title{
ZARZĄDZANIE JAKOŚCIĄ USKUG A DZIAŁALNOŚĆ PRZEDSIĘBIORSTW SEKTORA BANKOWEGO
}

\begin{abstract}
Streszczenie
Bankowość należy do najdynamiczniej rozwijających się usług w gospodarce światowej. Udział transakcji finansowych, za którymi nie następuje fizyczny przepływ towarów ani usług materialnych, w znaczny sposób przewyższa wartość tradycyjnego obrotu handlowego. Jednym z wielu środków będących w dyspozycji dzisiejszego banku, dzięki któremu może on dostatecznie wyróżniać się na rynku, jest wysoka jakość obsługi. Działania w kierunku wdrażania jakości mogą zapewnić bankowi działalność przynoszącą dochody zapewniające rozwój. Wzrastająca konkurencja na rynku usług bankowych spowodowała, że banki dokonują weryfikacji stosunku do swoich klientów. Celem niniejszego artykułu jest przybliżenie tematyki zarządzania jakością usług w odniesieniu do tak specyficznego rodzaju działalności, jaką jest działalność banków. Artykuł opiera się na studiach literaturowych $\mathrm{z}$ tego zakresu.
\end{abstract}

Słowa kluczowe: zarządzanie, jakość, usługi, bank

\footnotetext{
*Adres e-mail:kasiasz@wneiz.pl.
} 


\section{Wprowadzenie}

Dynamicznie rozwijający się sektor usług finansowych wymaga stosowania przez te instytucje w większym stopniu reguł i narzędzi marketingu, a także całego dorobku metodologii jakości, by sprostać narastającej konkurencji. Zaspokojenie potrzeb i oczekiwań klientów może odbywać się tylko przez gwarantowanie, że jakość działania i osiągane wyniki finansowe będą realizowane za pomocą przyjętych założeń polityki jakościowej. Produkt i usługa, którymi klient jest zainteresowany, znajduje się w ofercie wielu banków, dlatego też nie stanowi już głównego kryterium branego pod uwagę przez klienta przy wyborze banku. Bank, który pragnie odgrywać znaczącą rolę na rynku, wyznaczając główne cele działalności, nie może pominąć problemu jakości obsługi, szczególnie gdy wymogiem staje się mierzenie stopnia satysfakcji z poziomu dostarczonych klientowi usług bankowych. Celem niniejszego artykułu jest przybliżenie tematyki zarządzania jakością usług w odniesieniu do tak specyficznego rodzaju działalności, jaką jest działalność banków. Artykuł opiera się na studiach literaturowych z tego zakresu.

\section{Specyfika działalności usługowej}

Do momentu zdefiniowania usługi w normach ISO 9000 istniała ogromna liczba propozycji wyjaśnienia jej istoty. Do najbardziej znanych należała definicja P. Kotlera, który uważał, że „usługa jest dowolnym działaniem, jakie jedna strona może zaoferować innej, przy czym może być ono związane lub nie z produktem fizycznym"1. Można wyodrębnić pewne charakterystyczne cechy usług. Według J. Łańcuckiego są to²:

- niematerialny charakter (nienamacalność),

- jednoczesność świadczenia i korzystania z usługi,

- nietrwałość i brak możliwości magazynowania, ścisły związek usługi z osobą wykonawcy,

- heterogeniczność (niejednorodność),

1 P. Kotler, Marketing. Planowanie, wdrażanie i kontrola, Gebethner \& S-ka, Warszawa 1994 , s. 426 .

2 J. Łańcucki, Jakość ustug, „Problemy Jakości” 1997, nr 8, s. 4. 
- komplementarność i substytucyjność usług i dóbr materialnych,

- niemożność nabycia prawa własności usługi.

Przedsiębiorstwa usługowe charakteryzują się swoistymi problemami zarządzania wynikającymi $z^{3}$ :

a) zarządzania świadczeniem usług (niematerialną sferą usług) - jakość usług wyraża się nie tylko dopasowaniem ich do produktu, ale również sposobem ich świadczenia;

b) nietrwałości - planowanie usług wymaga starannego ich dopasowania do wielkości popytu, w przeciwieństwie bowiem do dóbr materialnych usługi nie mogą być magazynowane;

c) wzajemnego oddziaływania (interakcji) między producentem i konsumentem - o atmosferze wzajemnych kontaktów decydują pierwsze trzy minuty spotkania, w związku z tym wiarygodność w kontaktach jest ważna, gdyż umiejętnie okazana może wywołać satysfakcję bądź w przypadku niewłaściwej obsługi - efekt przeciwny;

d) nieuchwytności istoty jakości, która jest cechą wysoce subiektywną - to, co przez jedną osobę zostanie ocenione jako wspaniałe, przez drugą może być przyjęte jako byle jakie.

\section{Specyfika sektora usług bankowych}

Szybkie zmiany środowiska ekonomicznego, deregulacja, rozwój technik teleinformatycznych i wynikający stąd wzrost konkurencji na rynku usług finansowych wpłynęły na ewolucję orientacji działania banków z koncepcji dystrybucyjnej (koncentracja na produkcie) na marketingową (koncentracja na kliencie) ${ }^{4}$. W sposób niebudzący wątpliwości można przyjąć tezę, że obsługa to w zasadzie jedyny towar, jaki banki mają na sprzedaż. Jednym z wielu środków będących w dyspozycji dzisiejszego banku, dzięki któremu może on dostatecznie wyróżniać się na rynku, jest wysoka jakość obsługi. Działania w kierunku wdrażania jakości mogą zapewnić

3 H. Drummond, W pogoni za jakościa, Dom Wydawniczy ABC, Warszawa 1998, s. 96-98.

4 Ch.T. Ennew, M. Wright, D.Th. Waites, Strategic Marketing in Financial Services: Retrospect and Prospect, „International Journal of Bank Marketing” 1993, Vol. 11, No. 6, s. 12-13, za: A. Kłopocka, Oczekiwania klientów a jakość detalicznych usług bankowych, „Bank i Kredyt”2002, nr 8, s. 24-25. 
bankowi działalność przynoszącą dochody zapewniające rozwój. Rozwój to nowe technologie, nowe kanały dystrybucji, a zatem większe możliwości zaspokajania potrzeb, a nawet wychodzenia ponad oczekiwania klientów. To z kolei powoduje poszerzenie wpływów poprzez zwiększenie bazy klientów i wpływa na lojalność klientów ${ }^{5}$.

Przyjmując, że celem działalności banku jest wzrost udziału w rynku oraz trwała pozycja na rynku usług finansowych, bank musi zapewnić własny poziom jakości dostarczanych przez siebie usług ${ }^{6}$. Nie wystarczy zainteresować klienta oferowanym produktem i nakłonić go do zakupu. Uzyskanie przewagi konkurencyjnej (przekładającej się na wynik finansowy) wymaga utrzymania pozyskanego klienta i przekształcenia go w stałego odbiorcę, a nawet orędownika banku. Żeby taka transformacja mogła nastąpić, niezbędne jest zadowolenie klienta z usługi, a ta satysfakcjonuje nabywcę tylko wtedy, jeśli jest odpowiedzią na jego potrzeby i oczekiwania.

Rola konsumpcji usług w ogólnej strukturze spożycia ludności i szybki wzrost wymagań nabywców co do jakości powoduje przyjmowanie w zarządzaniu przedsiębiorstwem zasad TQM, a przede wszystkim generalnego kanonu tej filozofii, jakim jest niezmienna orientacja na klienta rzeczywistego i potencjalnego oraz konieczność zaspokojenia jego bieżących i przewidywanych potrzeb ${ }^{7}$. Dlatego też problematyka jakości w zarządzaniu bankiem wciąż stanowi przedmiot dużego zainteresowania $\mathrm{w}$ teoretycznych rozważaniach, a także w praktyce bankowej.

\section{Jakość usług w działalności banków}

Jedną z bardziej charakterystycznych usług jest usługa bankowa, która cechuje się niematerialnym charakterem, a także niemożliwością nabycia do niej praw własności. Usługi bankowe stanowią element usług finansowych, a te w rozumie-

5 H. Krajewski, Do jakości zewnętrznej przez jakość wewnętrzna, w: Zarzadzanie jakościa ustug w bankach $i$ zakładach ubezpieczeń, red. J. Garczarczyk, Materiały Konferencyjne Akademii Ekonomicznej w Poznaniu, Poznań 2000, s. 57.

6 D. Sobolewski, Zaufanie w programach zapewnienia jakości ushug finansowych dla strategicznych klientów banku, w: Marketing ustug profesjonalnych. t. 1, red. K. Rogoziński, Materiały Konferencyjne Akademii Ekonomicznej w Poznaniu, Poznań 2000, s. 212.

2000, nr 10, s. 4. 
niu standardów Unii Europejskiej to „wszystkie usługi o charakterze finansowym, świadczone przez usługodawcę finansowego z jednej ze stron układu"8.

W ostatnich latach instytucje bankowe zostały poddane intensywnej konkurencji i wzrostowi oczekiwań klientów. Czynniki, które przyczyniły się do takiego stanu rzeczy, to globalizacja, postęp technologiczny i zmiany w regulacjach rządowych ${ }^{9}$. Dlatego też jakość usług jest najważniejszym aspektem w bankowości. Sukces w biznesie może być wzmocniony, jeśli będzie sumiennie szukać nowych i bardziej skutecznych sposobów poprawy jakości swoich sposobów służenia klientowi. Jeśli chodzi o bankowość, to skuteczne narzędzia TQM mogą przynieść wartość dodaną w wewnętrznych oddziałach banków oraz swoim pracownikom pierwszej linii ${ }^{10}$.

Na rynku bankowym mamy zatem do czynienia z usługą bankową, której mogą towarzyszyć dobra materialne i inne usługi o mniejszym znaczeniu. W praktyce używamy określenia ,produkt bankowy”, jednak bardziej precyzyjne sformułowanie to „usługa bankowa" ${ }^{11}$. Produkt bankowy to usługa o niematerialnym charakterze. Powstaje ona wprawdzie w wyniku zastosowania materialnych czynników (np. wyposażenie techniczne, formularze), jednak odmiennie niż w przypadku dóbr bez stosowania materialnych surowców i półproduktów, które wchodzą w skład produktu finalnego i tworzą materialną substancję dóbr. W przeciwieństwie więc do produktów nie można ich dostrzec, spróbować, usłyszeć czy też poczuć, zanim się je kupi ${ }^{12}$.

Usługi bankowe to kategoria dynamiczna, która obejmuje różnorodnie korzyści oferowane ich nabywcom. Strukturę usługi bankowej tworzy rdzeń (podstawowe korzyści), usługa rzeczywista (cechy i elementy decydujące o sile postrzegania usługi przez nabywców i konkurencję) i usługa poszerzona (obejmująca dodatkowe

8 E. Skrzypek, Zarządzanie jakościa ustug bankowych, w: Zarządzanie jakościa ustug w bankach i zakładach ubezpieczeń, red. J. Garczarczyk, Materiały Konferencyjne Akademii Ekonomicznej w Poznaniu, Poznań 2000, s. 45.

9 C.H. Cheng, M.S. Madan, J. Motwani, Implementing Quality Management in the Banking Services Sector, „Total Quality Management” 1996, Vol. 7, issue 4, s. 347.

10 B. Appat, Total Quality Management in Banking. Some Newer Approaches, http://bankingtqm. blogspot.com/2011/12/total-qualitymanagement-in-banking-some.html (1.12.2015).

11 Ibidem.

12 R. Daniluk, Czynniki wptywające na jakość ustug w banku, „Problemy Jakości” 2000, nr 4, s. 35 . 
korzyści mające wpływ na przewagę konkurencyjną) $)^{13}$. Definicja jakości wdrażana w przedsiębiorstwach bankowych składa się z czterech elementarnych pozycji ${ }^{14}$ :

- wewnętrznej doskonałości banku,

- efektywności i sprawności,

- najwyższego poziomu obsługi klienta,

- struktury organizacyjnej skierowanej na jakość.

Jakość można również przedstawić w postaci graficznej, która pokazuje, że jakość usługi jest uzależniona od wpływu wykonania usługi na wrażenie klienta (rysunek 1).

Rysunek 1. Jakość w banku

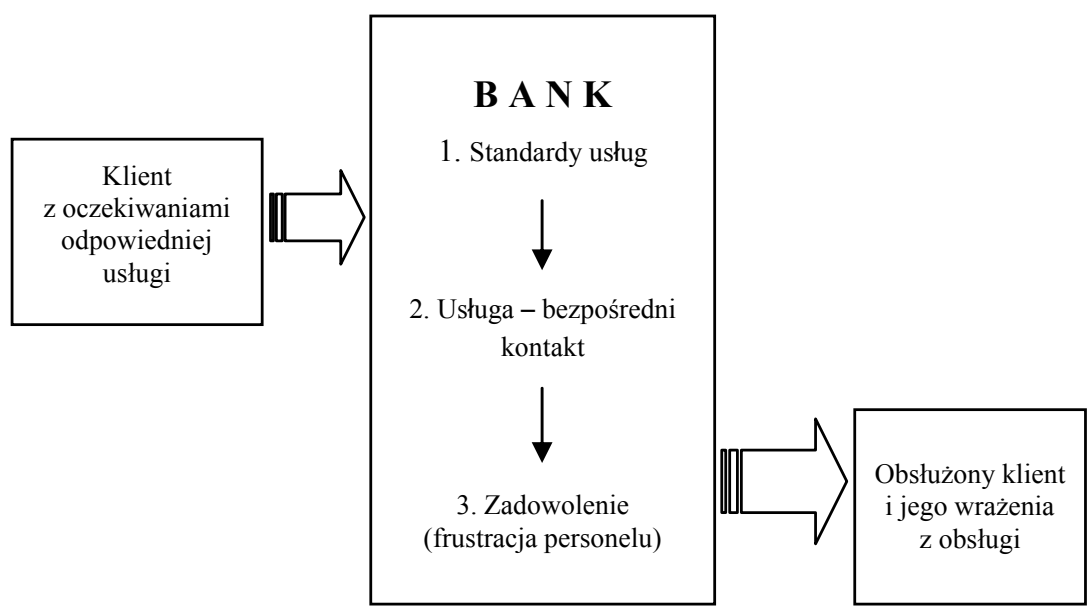

Źródło: S. Walukiewicz, Zarzadzanie przez jakość w bankach, w: Znaczenie jakości w przedsiębiorstwach bankowych, red. D. Delekta, ,Firma i Rynek. Zachodniopomorska Szkoła Biznesu” 2000, nr 1, s. 26.

Mogłoby się wydawać, że obsługa klienta to najważniejszy element stanowiący o konkurencyjności instytucji bankowej. Jednak jakość obsługi to nie wszystko. Na jakość w usługach finansowych składają się takie elementy, jak:

13 E. Skrzypek, op.cit., s. 45.

14 Znaczenie jakości w przedsiębiorstwach bankowych, red. D. Delekta, „Firma i Rynek” 2000, nr 1, s. 25. 
a) struktura organizacji przyczyniająca się do odpowiedniego podziału kompetencji w zakresie podejmowania decyzji dotyczących jakości;

b) kultura organizacji, sprzyjająca poczuciu odpowiedzialności za jakość przez wszystkich pracowników;

c) zaangażowanie kierownictwa w tworzenie polityki jakości i jej konsekwentne wdrażanie $\mathrm{z}$ głębokim przekonaniem o słuszności takiego postępowania $^{15}$.

Przedstawione powyższe założenia można uznać za podstawowe, jeśli zostaną one przyjęte w strategii zarządzania przez jakość w banku. Przedstawia to rysunek 2.

Rysunek 2. Podstawowe założenia strategii TQM w banku

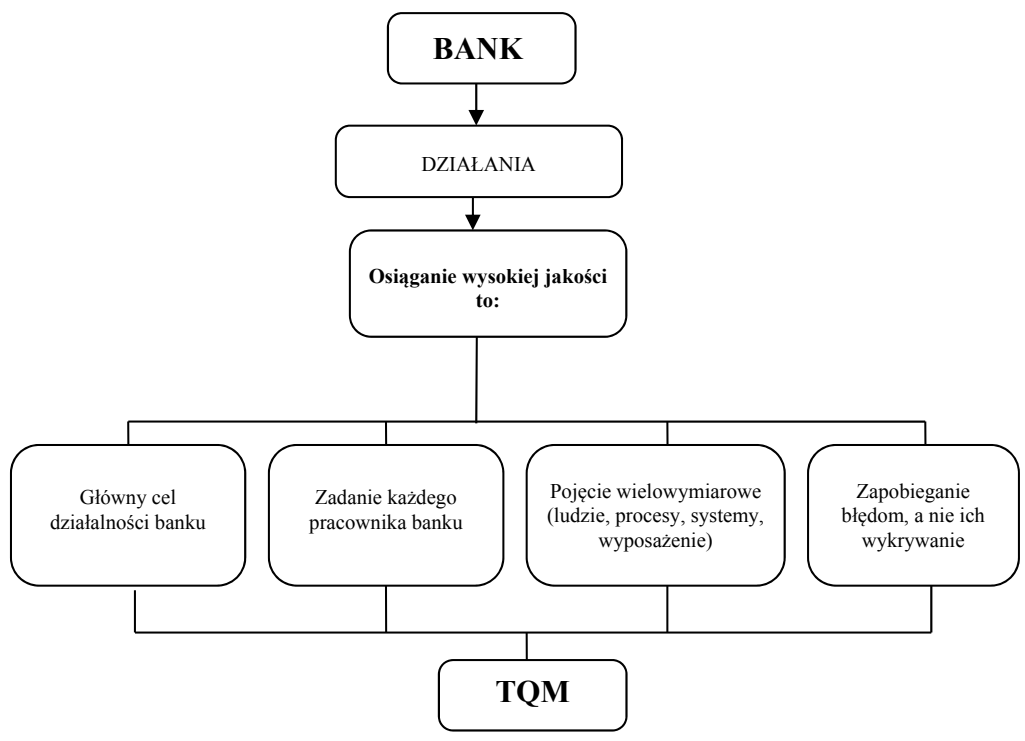

Źródło: opracowanie własne na podstawie J. Frąś, Zarządzanie jakościa w instytucjach gospodarczych, Wydawnictwo Naukowe Uniwersytetu Szczecińskiego, Szczecin 2000, s. 154.

15 K. Opolski, Zarządzanie przez jakość w ustugach finansowych, w: Zarządzanie jakościa ustug w bankach i zakładach ubezpieczeń, red. J. Garczarczyk, Materiały Konferencyjne Akademii Ekonomicznej w Poznaniu, Poznań 2000, s. 19. 
Do osiągnięcia tej powszechnej, obejmującej cały bank strategii niezbędne jest opracowanie polityki jakości w postaci dokumentu, tzw. księgi jakości. Musi być ona przedstawiona wszystkim pracownikom, a jeśli to konieczne - również dostawcom, kooperantom i klientom. Na politykę jakości składają się ${ }^{16}$ :

a) misja banku - określa, co organizacja chce osiągnąć i w jakim kierunku zmierza;

b) filozofia jakości - zawiera się w wymaganiach i oczekiwaniach klientów, powszechnym zaangażowaniu, odpowiedzialności na wszystkich poziomach struktury organizacyjnej oraz niekończącym się zaangażowaniem w proces poprawy jakości;

c) sposoby osiągania jakości - czyli główne elementy działalności, które są określane przez konkretne cele organizacji; obejmują one m.in. unikanie błędów i usterek, zapewnianie jakości przy minimalnych kosztach, przestrzeganie terminów, uprzejmość obsługi;

d) środki do osiągania poprawy jakości - pomoc i zasoby potrzebne do realizacji polityki jakości, np. szkolenia i treningi, pomoc i współpraca, pomiar jakości.

Jakość, podobnie jak reputacja, jest budowana długo, ale bardzo szybko można ją stracić. Opiera się na rzeczywistych działaniach banku, a nie na jego wizerunku. Reputację banku świadczącego wysokiej jakości usługi buduje się na niepopełnianiu błędów oraz wytrwałym spełnianiu wymagań klientów. Jakość musi obejmować wszystkie aspekty działalności organizacji, a nie tylko produkty lub ich elementy. Jakość usług bankowych opiera się w dużym stopniu na ludziach, dlatego zaangażowanie i praca każdego pracownika ma tu duże znaczenie ${ }^{17}$.

Aby osiągnąć założony cel, jakim jest efektywne zarządzanie przez jakość, działania te muszą przyjąć charakter procesu wdrażanego na całym obszarze działalności bankowej. Jakość to umiejętność trwałego zaspokajania wymagań i oczekiwań konsumenta. Mówiąc o jakości w przypadku usług bankowych, powinno się zwrócić uwagę, że jakość usługi to jakość kontaktu, który zachodzi między pracownikiem in-

16 K. Opolski, Strategia jakości w nowoczesnym zarzadzaniu bankiem, Instytut Naukowo-Wydawniczy Olympus-Centrum Edukacji i Rozwoju Biznesu, Warszawa 1998, s. 28-30.

17 Ibidem. 
stytucji finansowej a klientem. W efekcie jest to miara, na ile wrażenia (odczucia) po uzyskaniu usługi pokrywają się z oczekiwaniami klienta przed jej otrzymaniem ${ }^{18}$.

Wzrost konkurencji na rynku finansowym sprawia, iż jakość stała się podstawowym czynnikiem zdobywania przewagi konkurencyjnej wyznaczającym pozycję konkurencyjną banku. Wymaga to nie tylko systematycznego uaktualniania i wzbogacania oferty podażowej, ale poznawania i zaspokajania zmieniających się ustawicznie potrzeb i oczekiwań klientów, a przez to podnoszenia jakości świadczonych usług $^{19}$. Banki chcące utrzymać się w wyścigu konkurencyjnym winny ze stałego polepszania jakości oferowanych usług uczynić priorytet ${ }^{20}$. Stąd też, dążąc do zaspokojenia potrzeb i oczekiwań klientów, powinny wdrażać standardy jakości usług, systemy zarządzania jakością oraz dążyć do spełnienia wymogów stawianych przez uznane na świecie normy jakości.

\section{Podsumowanie}

Jak wynika z powyższych rozważań, jedyną metodą walki konkurencyjnej w przypadku instytucji bankowych jest podnoszenie jakości świadczonych usług. Nie można poprzestać na stosowaniu się do ustalonych norm i procedur. Należy nieustannie wykraczać poza nie, szukać nowych rozwiązań, poświęcać wiele uwagi potrzebom klientów zarówno zewnętrznych, jak i wewnętrznych - pracowników. Najważniejszym zadaniem jest przełamanie barier świadomościowych oraz pełne zaangażowanie załogi w możliwie jak najkrótszym czasie. Poziom usług świadczonych przez polskie banki wciąż jeszcze odbiega od poziomu reprezentowanego przez banki krajów Unii Europejskiej. Proces zmian jest długotrwały, a fakt członkostwa Polski w Unii Europejskiej stawia przed nimi duże możliwości działań w kierunku poprawy poziomu świadczonych usług.

18 S. Walukiewicz, Zarządzanie przez jakość w bankach, w: Znaczenie jakości w przedsiębiorstwach bankowych, red. D. Delekta, „Firma i Rynek” 2000, nr 1, s. 26.

19 J. Garczarczyk, Determinanty jakości ustug finansowych $w$ ocenie menedżerów i klientów, w: Zarzadzanie jakościa ustug w bankach i zakładach ubezpieczeń, red. J. Garczarczyk, Materiały Konferencyjne Akademii Ekonomicznej w Poznaniu, Poznań 2000, s. 175.

20 A. Sekóła, Wpływ personelu na jakość usług bankowych, w: Marketing usług profesjonalnych. t. 1, red. K. Rogoziński, Materiały Konferencyjne Akademii Ekonomicznej w Poznaniu, Poznań 2000, s. 200. 


\section{Literatura}

Appat B., Total Quality Management in Banking. Some Newer Approaches, http://bankingtqm. blogspot.com/2011/12/total-qualitymanagement-in-banking-some.html (1.12.2015).

Cheng C.H., Madan M.S., Motwani J., Implementing Quality Management in the Banking Services Sector, „Total Quality Management” 1996, Vol. 7, Issue 4.

Daniluk R., Czynniki wpływajace na jakość ustug w banku, „Problemy Jakości” 2000, nr 4.

Drummond H., W pogoni za jakościa, Dom Wydawniczy ABC, Warszawa 1998.

Frąś J., Zarządzanie jakością w instytucjach gospodarczych, Wydawnictwo Naukowe Uniwersytetu Szczecińskiego, Szczecin 2000.

Garczarczyk J., Determinanty jakości ustug finansowych w ocenie menedżerów i klientów, w: Zarzadzanie jakościq ustug w bankach i zakładach ubezpieczeń, red. J. Garczarczyk, Materiały Konferencyjne Akademii Ekonomicznej w Poznaniu, Poznań 2000.

Kłopocka A., Oczekiwania klientów a jakość detalicznych ustug bankowych, „Bank i Kredyt” 2002, nr 8.

Kotler P., Marketing. Planowanie, wdrażanie i kontrola, Gebethner \& S-ka, Warszawa 1994.

Krajewski H., Do jakości zewnętrznej przez jakość wewnętrzna, w: Zarzadzanie jakościq ustug w bankach i zakladach ubezpieczeń, red. J. Garczarczyk, Materiały Konferencyjne Akademii Ekonomicznej w Poznaniu, Poznań 2000.

Krzyżanowska M., Wajder R., Aspekty TQM w organizacji ustugowej, „Problemy Jakości” 2000, $\mathrm{nr} 10$.

Łańcucki J., Jakość ustug, „Problemy Jakości” 1997, nr 8.

Opolski K., Strategia jakości w nowoczesnym zarzadzaniu bankiem, Instytut Naukowo-Wydawniczy Olympus-Centrum Edukacji i Rozwoju Biznesu, Warszawa 1998.

Opolski K., Zarzadzanie przez jakość w ushugach finansowych, w: Zarzadzanie jakościq uslug $w$ bankach i zaktadach ubezpieczeń, red. J. Garczarczyk, Materiały Konferencyjne Akademii Ekonomicznej w Poznaniu, Poznań 2000.

Sekóła A., Wpływ personelu na jakość uslug bankowych, w: Marketing uslug profesjonalnych. t. 1, red. K. Rogoziński, Materiały Konferencyjne Akademii Ekonomicznej w Poznaniu, Poznań 2000.

Skrzypek E., Zarządzanie jakościa ustug bankowych, w: Zarządzanie jakościa ustug w bankach i zakładach ubezpieczeń, red. J. Garczarczyk, Materiały Konferencyjne Akademii Ekonomicznej w Poznaniu, Poznań 2000.

Sobolewski D., Zaufanie w programach zapewnienia jakości ushug finansowych dla strategicznych klientów banku, w: Marketing ustug profesjonalnych. t. 1, red. K. Rogoziński, Materiały Konferencyjne Akademii Ekonomicznej w Poznaniu, Poznań 2000. 
Walukiewicz S., Zarządzanie przez jakość w bankach, w: Znaczenie jakości w przedsiębiorstwach bankowych, red. D. Delekta, „Firma i Rynek” 2000, nr 1.

Znaczenie jakości w przedsiębiorstwach bankowych, red. D. Delekta, „Firma i Rynek” 2000, nr 1.

\title{
QUALITY MANAGEMENT AND SPECIFICITY OF BANKING SECTOR ENTERPRISES
}

\begin{abstract}
The fundamental purpose of this article is to enlighten the essence of achieving high bank service quality. The level of competition in this sector results in the fact that still quality is the essential factor in achieving competitive advantage. Every bank that wants to have a significant position in the market cannot forget about the high quality while elaborating on the strategy of its activity. The article proves that quality is the only method of surviving in the more and more competitive market.
\end{abstract}

Translated by Katarzyna Szopik-Depczyńska

Keywords: management, quality, services, banks

JEL Code: G21 
